\title{
Households' Willingness to Pay for Disaster Resilient Safe Drinking Water Sources in Southwestern Coastal Bangladesh
}

\author{
Md. Sariful Islam ${ }^{1}$ - Sonia Afrin ${ }^{1} \cdot$ Md. Nasif Ahsan ${ }^{1} \cdot$ Mohammed Ziaul Haider $^{1}$. \\ Tasnim Murad Mamun ${ }^{1}$ - Debasish Kumar Das ${ }^{1}$
}

Published online: 16 September 2019

(C) The Author(s) 2019

\begin{abstract}
Nonfunctionality of engineered water sources after two catastrophic cyclones-Sidr in November 2007 and Aila in May 2009-created acute scarcity of safe drinking water in coastal Bangladesh. The objective of this study was to estimate households' willingness to pay (WTP) for disaster resilient water sources in Dacope upazila of Khulna District in southwestern coastal Bangladesh. By applying the double bounded dichotomous contingent valuation method to a dataset of 250 randomly selected households, we found that the mean WTP is BDT 263 and that inaccessibility to functional safe drinking water sources is the most significant determining factor of households' WTP. Projecting mean WTP for a disaster resilient water source project in the study area, we measured a present value of aggregate WTP over project's life span worth about BDT 624 (USD 7.37) million, which is about 14.30 times the present value of project's aggregate establishment and maintenance cost. However, charging the local inhabitants a water tariff at mean WTP would lead to the exclusion of around 50\% of the people from getting access to the improved water services or create a free riding problem. Through simulation exercises this study determined that the socially optimal water tariff is BDT 50 per month. This tariff would not only generate revenue of more than five times the project cost but would also create access to disaster resilient improved drinking water sources for almost $99 \%$ of the people.
\end{abstract}

Md. Sariful Islam

sariful_ku@yahoo.com

1 Economics Discipline, Khulna University, Khulna 9208, Bangladesh
Keywords Bangladesh · Disaster resilient safe drinking water - Double bounded contingent valuation $\cdot$ Household willingness to pay

\section{Introduction}

Demand for safe drinking water is mounting with the increase in global population. Global demand for freshwater doubles in every 20 years while drinkable water stocks are depleting rapidly. As a consequence, dependency on contaminated water is increasing. Millions of people are suffering from chronic diseases like cholera, diarrhea, typhoid, and parasites due to drinking contaminated water (Curry 2010). Currently, around one in every nine of the global population lacks access, and around 844 million people do not have access to safe drinking water (World Economic Forum 2019). Arsenic and salinity contamination of water sources is the major cause creating scarcity of safe drinking water (Abedin and Shaw 2014). Climate change exacerbates this water scarcity further. The Intergovernmental Panel on Climate Change (IPCC) pointed out how climate change induces global warming, sea level rise, and frequent natural hazards, resulting in salinization in groundwater, rivers, and crop fields (Parry et al. 2007).

Bangladesh is the fifth most climate change induced disaster-prone country and experiences severe scarcity of safe drinking water (EHS 2011). Cyclones, storm surges, tidal waves, flooding, river erosion, and droughts of varied scales and severity are the most common climatic hazards that affect millions of coastal people every year and damage natural water sources (Mallick and Vogt 2011). To cope with this disastrous situation, government and nongovernment organizations have implemented various water 
treatment options: pond sand filters (PSFs), arsenic-free shallow tube wells (STWs), pipeline water (PLW), and rainwater harvesting (RWH) to provide safe drinking water (Yokota et al. 2001). About 38\% of the people use PSFs while STWs, RWH, open ponds, and other sources are used for drinking purposes by $30 \%, 13 \%, 10 \%$, and $9 \%$ of the people, respectively (Harun and Kabir 2013). These sources maintain Bangladesh's standard water quality in terms of odor, $\mathrm{pH}$, dissolved oxygen, hardness, calcium, magnesium, nitrate, sulphate, phosphate, turbidity, color, and bacterial contamination (Harun and Kabir 2013).

However, two recent catastrophic cyclones-2007 Cyclone Sidr and 2009 Cyclone Aila-damaged the functionality of PSFs, PLW, and STWs badly because these water interventions in the region were not disaster resilient (Dasgupta et al. 2011). The impacts of Cyclone Aila were more catastrophic than those of Cyclone Sidr and damaged the functionality of around 163 pond sand filters, 594 shallow tube wells, and 444 deep tube wells completely in Khulna and Shatkhira Districts in southwestern Bangladesh (JAC 2009). Harun and Kabir (2013) showed that almost $80 \%$ of the users are partially or completely dissatisfied with the water quality from these damaged water sources. Of the available tube wells, only a few provide year-round access to safe drinking water (DPHE 2009) since water from deep tube wells, shallow tube wells, and pond sand filters contains excessive sandy materials, arsenic, and pathogens (Safiuddin et al. 2003). Moreover, water scarcity increases in the dry season due to recurrent droughts and the upstream withdrawal of freshwater (Rahman and Ravenscroft 2003; Abedin and Shaw 2018).

Since the coastal regions of Bangladesh are susceptible to regular disastrous tropical cyclones with storm surges, refunctionalizing the damaged drinking water sources does not assure the sustainability of the water supply. A sustainable solution for providing safe drinking water can be the construction and continual management of disaster resilient water sources. However, the sustainability of this kind of supply intervention requires investment. Community-based financing can be an attainable solution. Community involvement is important for the successful implementation and maintenance of sustainable drinking water supply projects (Habiba et al. 2012). This study assessed households' willingness to pay (WTP) for disaster resilient safe drinking water sources in southwestern coastal Bangladesh, applying the double bounded dichotomous contingent (DBDC) valuation approach. We interviewed 250 randomly selected households from Dacope upazila, Khulna District in southwestern coastal Bangladesh during April-May 2016. Since the drinking water crisis increases during the hot summer respondents would tend to accept higher WTP bids, which may have led to an overestimation of WTP. Although this potential overestimation is a limitation of this study, it might have two advantages: (1) it controls the effects of seasonal variation of water demand on WTP estimation; and (2) it considers households' disutility of sufferings from extreme water crisis in computing WTP.

\section{Salinity Contamination and Potential Health Risks, Study Area, and Sampling Strategy}

The coastal region of Bangladesh, along with the Bay of Bengal, is a part of the Ganges Delta, where large tidal rivers are connected with the surface and groundwater bodies through various channels of estuaries and water inlets, intruding salinity even $100 \mathrm{~km}$ inland (Rahman and Bhattacharya 2006). The region has experienced an around $26 \%$ rise in salinity since 1980 (Mahmuduzzaman et al. 2014). It may increase at an even higher rate in coming years due to the increase in upstream water withdrawal, the reduction in river flows, climate variability induced low rainfall, sea-level rise, and natural hazards. The rise of salinity in the drinking water is likely to create an increasingly disastrous situation through increasing health risks (Talukder et al. 2016).

The World Health Organization (WHO 2004) reported that salinity intrusion is more responsible than arsenic contamination in creating water scarcity in southwestern Bangladesh. The major reasons, summarized by Finan (2009), behind the salinity intrusion into the drinkable water sources are: natural hazards, water withdrawal from upstream of the transboundary rivers, and the excessive presence of sodium chloride in the surface water. Salinity intrusion into ground and freshwater aquifers makes the local people heavily dependent on rainwater. However, rainwater can support people only 6-7 months in the year, while they face severe water scarcity in the remaining 5-6 months. People take in around 5.92-11.7 g of sodium chloride per day through drinking water (Rasheed et al. 2016), whereas the acceptable limit is less than $5 \mathrm{~g} /$ day per person (WHO 2012). Excessive salt intake induces the prevalence of severe health problems, such as hypertension, and other chronic diseases, as well as miscarriages (Talukder et al. 2016). Exposure to salinity also increases the risk of gestational hypertension and (pre)eclampsia (Khan et al. 2011). About half of the rural people exceed the normal blood pressure threshold (Khanam et al. 2015), a major risk factor for cardiovascular and renal diseases (Appel 2010). Frequent outbreaks of skin diseases, fever, dysentery, and diarrhea are also reported in the salinity affected regions (Abedin et al. 2012).

In 2016, cardiovascular diseases alone account for almost 30\% of total deaths in Bangladesh (WHO 2018). A small reduction $(10 \mathrm{~mm} \mathrm{Hg})$ in systolic blood pressure 
would reduce mortality from all major cardiovascular diseases by $13 \%$ on an average (Ettehad et al. 2016). The prevalence rate of diarrhea among infants and children is almost 52\% higher in high saline regions than in moderate saline regions. The rate of suffering from indigestion is also $10 \%$ higher in the high saline regions (Abedin et al. 2014). Carrying heavy jars of drinking water for long distances spreads gynecological disorders among women (Abedin et al. 2014). Various complications during pre- and postpregnancy periods are positively associated with drinking saline water (Scheelbeek et al. 2016). The prevalence of black spot skin disease also varies from moderate to high saline regions by 10-22\% (Abedin et al. 2014). Das et al. (2019) showed that a $100 \mathrm{mg}$ increase in salinity per liter of drinking water raises the annual health cost by USD 3.28 per household in southwestern Bangladesh. Out of the 11 districts in this region, Bagerhat, Khulna, and Satkhira Districts are more saline prone because salinity is intruded by cultivating shrimp into around $80 \%$ of the total area (Habiba et al. 2014). This is because for cultivating shrimp, farmers make channels from saline water sources-the sea and sea-connected tidal rivers - to inundate their inland shrimp ponds with brackish saline water. Tidal flooding gradually accelerates this intrusion rate. Additionally, transboundary water withdrawal by India through barrages increases salinity (Baten and Titumir 2016).

Cyclone Aila aggravated this water scarcity by damaging water interventions severely. Because among these three districts Khulna is the most vulnerable to water scarcity (Habiba et al. 2014) we selected Khulna District as our broad study area. We then selected Dacope upazila (subdisdrict) as the most affected by Cyclone Aila. There are three polders (no. 31, 32, and 33) and each polder includes three unions (rural areas) (DPHE 2015). Seven out of these nine unions were reported as severely affectedCyclone Aila damaged the functionality of 521 (23\%) of 2292 water interventions completely-39\% of pond sand filters and $85 \%$ of water pipelines (Table 1). The water quality of partially damaged interventions was also degraded significantly.
Out of the seven severely affected unions, we selected the most severely damaged five unions purposively (Pankhali and Tildanga of polder 31, Kamarkhola and Sutarkhali of polder 32, and Kailashgang of polder 33). Following the National Oceanic and Atmospheric Administration's (NOAA) suggestion for collecting data (Arrow et al. 1993)-considered the most reliable method for collecting data in contingent valuation studies (Carson 2000) - we designed our face-to-face interview schedule. For valuation studies, deciding the basis for willingness to pay-whether individual (Kealy et al. 1990) or household level (McConnell 1995) - is a major challenge. Following Banga et al. (2011), we decided to ask about household level WTP. An interview schedule was utilized to conduct a face-to-face interview with the respondents (head or any decision-making person being present at the time of interview) of each household. By choosing one village from each union and thus, five villages of the selected five unions, 250 randomly selected households (50 from each union) were interviewed during April-May 2016.

\section{Methods}

In this section, we have outlined the method of estimating households' willingness to pay for disaster resilient water sources, focusing on the selection of valuation approach, framework for different improved disaster resilient water provisioning scenarios, and econometric specification.

\subsection{Selection of the Valuation Approach}

Since the pricing system of a conventional market cannot determine the demand for disaster resilient water sources, nonmarket valuation approaches are usually adopted for determining environmental goods' demand. These approaches broadly include indirect and direct approaches. Direct approaches such as contingent valuation (CV) and choice experiment (CE) are more convenient and comprehensive compared to indirect approaches (for example, cost of illness, hedonic pricing, or travel cost methods).

Table 1 Functional and nonfunctional water interventions in seven unions of Dacope upazila, Khulna District, Southwestern Bangladesh, after 2009 Cyclone Aila. Data source DPHE (2015)

\begin{tabular}{lccrr}
\hline Water intervention & Functional & Nonfunctional & Total & Damage $(\%)$ \\
\hline PSF (Pond Sand Filter) & 391 & 250 & 641 & 39 \\
Pipeline (GIZ) & 6 & 35 & 41 & 85 \\
STW (Shallow Tube well) & 1114 & 236 & 1350 & 17 \\
Total & 1771 & 521 & 2292 & 23 \\
\hline
\end{tabular}

${ }^{\mathrm{a} D e u t s c h e ~ G e s e l l s c h a f t ~ f u ̈ r ~ I n t e r n a t i o n a l e ~ Z u s a m m e n a r b e i t ~(G I Z) ~}$ 
This is because these indirect approaches cannot include any reflection of environmental degradation (that is, water contamination or scarcity) induced pain, suffering, and discomforts in WTP computation (EPA 2000). Within the set of direct approaches, although CE approaches are more efficient than CV approaches, widespread applications of $\mathrm{CV}$ to compute WTP for avoiding individual risk exposure have been observed in valuation studies (Dekker et al. 2011), because WTP in CV is derived from the expected utility comparison for different risk levels. It shows that WTP increases with the increase in utility obtained from a risk reduction (Johansson 1995). This approach is more suitable in situations where contamination exposure varies widely across both individual and community levels (Khan et al. 2014). Another reason is that with the CV approach data collection and management procedures are cheaper, easier, and computationally friendlier to process than with the CE approach. Moreover, the double bounded dichotomous choice (DBDC), a type of CV method, is qualitatively almost the same as $\mathrm{CE}$, if hypothetical biases during respondents' WTP elicitation can be controlled. Therefore, we chose the DBDC technique to estimate household level WTP for disaster resilient improved drinking water sources.

\subsection{Theoretical Model for Estimating Willingness to Pay}

The DBDC framework is based on random utility theory. The choice among the available alternatives, including status quo (current situation) and several improvement scenarios, are made by respondents through utility comparisons. The alternative that yields the highest utility is the preferred choice (McFadden 1973; Louviere et al. 2000).

$U_{i}=V_{i}+\varepsilon_{i}$

Equation 1 states that overall utility $U_{i}$ includes two components: indirect utility $\left(V_{i}\right)$ and stochastic component $\left(\varepsilon_{i}\right)$. Here, $V_{i}$ is the function of the improvement alternatives and respondents' socioeconomic characteristics. Assuming a set consists of all possible improvement alternatives, including $i$ and $j$, McFadden's (1973) probability of choosing the $i$ instead of the $j$ alternative by $n^{\text {th }}$ respondent is:

$P_{n}(i)=\frac{\exp ^{\mu V_{i n}}}{\sum_{j \in C_{n}} \exp ^{\mu V_{i n}}}$

Since the indirect utility function is linearly and additively separable (Louviere et al. 2000), it can be shown as follows:

$V_{\text {in }}=\alpha_{\text {in }}+\beta_{i} X_{i}+\gamma Z_{n}+\delta\left(Y_{n}-C_{i}\right)$ where $\alpha_{i n}$ is scale parameters, capturing intrinsic preference for alternarovement sof respondent $n$. Additionally, $\mu, \beta_{i}, \gamma$, and $\delta$ are coefficients for $X_{i}$, features of improved alternatives $i$; $Z$, respondent $n$ 's socioeconomic characteristics; $C$, offered bids; $Y$, household income. Therefore, the last term of Eq. 3 shows that WTP for improvement alternative $i$ reduces respondents' disposable income. Respondents' preference of an improved alternative depends on alternative offers, their socioeconomic characteristics, and the offered bids.

\subsection{Framework for Disaster Resilient Improved Drinking Water Sources}

Following Hanemann and Kanninen's (2001) suggestion, we designed the contingent survey mechanism in three steps: (1) focus group discussions (FGDs); (2) pretesting the survey instruments; and (3) "cheap talk" ${ }^{1}$ with respondents to reduce the hypothetical bias. We conducted five FGD sessions, one in each of the selected five unions. Ten respondents participated in each session. Based on the findings from these FGDs, we prepared a draft contingent valuation survey schedule with close-ended questions, with initial and follow-up bids. This draft schedule was then pretested with 40 respondents. Necessary modifications identified from this pretesting were addressed and the bid vectors for four improvement scenarios were finalized accordingly for the schedule (Table 2).

All of these scenarios are improved PSF versions, compared to existing PSFs. To select pragmatic attributes for designing efficient, sustainable, and easily accessible disaster resilient improved water interventions, we had interactive discussions with the community people, nongovernmental organizations (NGOs), and Department of Public Health Engineering (DPHE) engineers assuming the proposed (improved) interventions as more efficient, userfriendly, cost-effective, and durable. The signature feature of the interventions is that all improved PSFs are to be surrounded by brick fence resilient to cyclones and storm surges.

In improved scenario 1, DPHE authority would refunctionalize the existing damaged PSFs by incorporating disaster resilient attribute-brick fence only. This is expected to significantly reduce people's intake of sodium chloride but not substantially remove pathogens. Even though the attributes taste, color, and odor are better under

\footnotetext{
${ }^{1}$ Cheap talk is a concomitant instrument of contingent valuation approach used to remind respondents advantages and disadvantages of each attributes elaborately and clearly compared to their status quo; and state that choice of improved plan will reduce their consumption expenditure before making their selection. It is useful to reduce hypothetical bias in eliciting their WTP toward improved plans (Lusk 2003).
} 
Table 2 Attributes for the improvement plan for the study area in southwestern coastal Bangladesh

\begin{tabular}{|c|c|c|c|c|c|}
\hline \multicolumn{2}{|c|}{$\begin{array}{l}\text { Attributes } \\
\text { Signature feature }\end{array}$} & \multicolumn{4}{|c|}{ Brick fence: It makes interventions under all improvement scenarios resilient to cyclonic storms with surges } \\
\hline \multicolumn{6}{|c|}{ Activity } \\
\hline (1) & Refunctionalize PSF & Yes & Yes & Yes & Yes \\
\hline (2) & Install PSF in non-PSF pond & No & Yes & Yes & Yes \\
\hline (3) & Excavate and install PSF & No & No & Yes & Yes \\
\hline (4) & Removal of sediment & No & No & No & Yes \\
\hline (5) & Quality control & No & Once a year & Twice a year & Quarterly \\
\hline \multicolumn{6}{|c|}{ Expected outcomes } \\
\hline (1) & Resilient to cyclone & Less & Moderate & High & Fully \\
\hline (2) & Safety to health & Less & Moderate & High & Fully \\
\hline (3) & Taste/color/odor & Somewhat satisfactory & Moderately satisfactory & Highly satisfactory & Excellent \\
\hline (4) & Meets standards & No & No & DOE & WHO \\
\hline \multicolumn{2}{|c|}{ Initial bid price } & $\mathrm{BDT}^{\mathrm{a}} 100$ & BDT 200 & BDT 300 & BDT 400 \\
\hline
\end{tabular}

DOE Department of Environment (https://doe.portal.gov.bd/sites/default/files/files/doe.portal.gov.bd/publications/d5bb5df3_3e3e_40f9_bdd3_ 9a72d29c16b5/Surface\%20and\%20Ground\%20Water\%20Quality\%20Report\%202016-.pdf), WHO World Health Organization (https://www. who.int/water_sanitation_health/dwq/fulltext.pdf), PSF pond sand filter; Currency: BDT (Bangladeshi Taka)

${ }^{\mathrm{a}}$ USD $1=$ BDT 84.66 as of 5 May 2018

scenario 1 than under the current situation, they are less improved than under scenarios 2, 3, and 4 (Table 2). Yearround quality control is not undertaken under this improvement plan, and the plan does not comply with either the Department of Environment (DOE) or with the World Health Organization (WHO) standards. Every household would be charged with only BDT 100 per month for access to improved scenario 1 .

More improved scenarios (2-4) would undertake additional activities: (1) refunctionalizing of existing PSFs; (2) installing the required number of PSFs in non-PSF ponds; (3) excavating new ponds and installing PSFs; (4) removing sediments from PSF pond beds; and (5) controlling water quality throughout the year. These improvement plans would provide sufficient resilience to disaster and purified drinking water with a satisfactory quality in terms of taste, color, and odor to satisfy the WHO standards. A tariff of BDT 400 per month is assigned to the most improved scenario.

Four survey teams, each with four members guided by an expert, were trained in the data collection method for the $\mathrm{CV}$ approach. During interviewing every respondent we explained the current situation of water scarcity and associated problems to that respondent. Then, the benefits of improving water quality, the costs associated with the improvements, and the financing procedure of activating the plans were presented to the respondents. Because WTP is directly linked to household income and consumption expenditure, we informed the respondents that the payment for choosing a more improved disaster resilient water plan will reduce their disposable income. Next, we directly raised a close-ended question of whether they were willing to pay for improvements or not. The respondents who answered "no" were further asked to select the reasons for their unwillingness from a list in the interview schedule. This approach helped us to differentiate the valid zeros from the protest bids. The respondents with a positive WTP were reminded to take into consideration their ability to pay and then asked to choose an improved option from the four alternative improvement scenarios (Table 2). Four different initial bids (BDT 100, 200, 300, and 400) were presented to the respondents. The follow-up higher bids were set as BDT 50 more and the lower bids as BDT 50 less than the respective initial bids.

At this point, the respondents were asked whether they were willing to pay the initial bid amount according to their chosen improvement plan. The respondents who accepted the initial bid were asked for a higher bid in a subsequent question. The respondents who accepted both the initial and the higher bids were coded as a "yes-yes" interval. The "yes-yes" interval implies that these respondents are actually willing to pay higher than the higher bid offer. In contrast, the acceptors of the initial bid who denied the follow-up higher bid were coded as a "yes-no" interval, implying that their WTP lies at some point between the initial and the higher bid offer. When the responses to the initial bid were "no," the respondents were offered a lower bid. The respondents who accepted this lower bid were 
coded as a "no-yes" interval, which implies that their WTP lies at some point between the initial and the lower bid offer. Non-acceptors of the initial bid who denied the lower bid were coded as a "no-no" interval, implying that their WTP is positive but less than the lower bid offer (Banga et al. 2011). Our survey teams also performed "cheap talk" that often reminds respondents about the importance of being truthful in assessing their WTP. This cheap talking procedure is effective in removing hypothetical bias from a nonmarket CV design (Lusk 2003).

\subsection{Econometric Specification}

In this DBDC framework, with a view to computing WTP for an improved water supply system, every respondent was asked to respond with an initial bid $\left(t^{I}\right)$ and a followup bid $\left(t^{F}\right)$. This creates a WTP interval for a specific respondent. When respondents answer "yes" to the initial bid, they are offered a higher follow-up bid $\left(t^{H}\right)$; if the initial response is "no", a lower bid $\left(t^{L}\right)$ is offered. Therefore, $t^{L}<t^{I}<t^{H}$. Thus, respondents' responses are categorized into four distinct WTP intervals:

1. Yes-Yes WTP interval: When respondent answers "yes" to both $t^{I}$ and $t^{H}, t^{H} \leq \mathrm{WTP}<\infty$.

2. Yes-No WTP interval: When respondent answers "yes" to $t^{I}$ and "n $t^{H}, t^{I} \leq \mathrm{WTP}<t^{H}$.

3. No-Yes WTP interval: When respondent answers "no" to $t^{I}$ and "yes" to $t^{L}, t^{L} \leq \mathrm{WTP}<t^{I}$.

4. No-No WTP interval: When respondent answers "no" to both $t^{I}$ and $t^{L}, 0 \leq \mathrm{WTP}<t^{L}$.

Therefore, we have four response probabilities, designed as follows:

$$
\begin{aligned}
\operatorname{Pr}(\text { Yes }, \text { Yes }) & =1-\mathrm{F}\left(t^{H}\right)=1-\frac{1}{1+e^{\left(\alpha+\beta t^{H}+\sum \gamma Z_{n}\right)}} \\
\operatorname{Pr}(\text { Yes }, N o) & =\mathrm{F}\left(t^{H}\right)-\mathrm{F}\left(t^{I}\right) \\
& =\frac{1}{1+e^{\left(\alpha+\beta t^{H}+\sum \gamma Z_{n}\right)}}-\frac{1}{1+e^{\left(\alpha+\beta t^{I}+\sum \gamma Z_{n}\right)}}
\end{aligned}
$$

$$
\begin{aligned}
\operatorname{Pr}(\text { No, Yes }) & =\mathrm{F}\left(t^{L}\right)-\mathrm{F}\left(t^{I}\right) \\
& =\frac{1}{1+e^{\left(\alpha+\beta t^{H}+\sum \gamma Z_{n}\right)}}-\frac{1}{1+e^{\left(\alpha+\beta t^{I}+\sum \gamma Z_{n}\right)}}
\end{aligned}
$$

$\operatorname{Pr}(N o, N o)=\mathrm{F}\left(t^{L}\right)=\frac{1}{1+e^{\left(\alpha+\beta t^{L}+\sum \gamma Z_{n}\right)}}$

From Eqs. 4-7, the log-likelihood function for our DBDC model is:

$$
\begin{aligned}
\log L= & \sum_{i=1}^{n}\left[\left[\left(R_{i}^{I} R_{i}^{H}\right) \log \left[F\left(\left(t_{i}^{H}-x_{i}^{\prime} \beta\right) / \sigma\right)\right]\right.\right. \\
& \left.+R_{i}^{I}\left(1-R_{i}^{H}\right) \log \left[F\left(\left(t_{i}^{H}-x_{i}^{\prime} \beta\right) / \sigma\right)-F\left(\left(t_{i}^{L}-x_{i}^{\prime} \beta\right) / \sigma\right)\right]\right] \\
& +R_{i}^{L}\left(1-R_{i}^{I}\right) \log \left[F\left(\frac{t_{i}^{I}-x_{i}^{\prime} \beta}{\sigma}\right)-F\left(\frac{t_{i}^{L}-x_{i}^{\prime} \beta}{\sigma}\right)\right] \\
& \left.\left.+\left(1-R_{i}^{I}\right)\left(1-R_{i}^{L}\right) \log F\left(\left(t_{i}^{L}-x_{i}^{\prime} \beta\right) / \sigma\right)\right]\right]
\end{aligned}
$$

where $R_{i}^{I}$ is the dichotomous response to the initial bid and $R_{i}^{I}=1$ implies respondents accept the initial bid and $R_{i}^{I}=$ 0 for otherwise. And, $R_{i}^{H}$ and $R_{i}^{L}$ are used to denote the responses for follow-up higher and lower bids, respectively. If respondents accept the, then $R_{i}^{H}=1$, and if they accept the lower bid, $R_{i}^{L}=1$. Maximizing Eq. 8 yields the following linear function.

$W T P\left(x_{i}^{\prime}, \varepsilon_{i}\right)=x_{i}^{\prime} \beta+\varepsilon_{i}$ with $\varepsilon_{i} \sim N\left(0, \sigma^{2}\right)$

Equation 9 permits us to estimate $\beta$ and $\sigma$; and their asymptotic standard errors. The estimated parameters are qualitatively the same as ordinary least square parameters. Therefore, parameters can be interpreted as the marginal change in WTP due to one unit change in the explanatory variable (Cameron and James 1987).

\section{Results and Discussion}

In this section, we first discuss the socioeconomic characteristics of households, then health impacts of drinking water from nonfunctional water sources, and households' willingness to pay for disaster resilient water sources and its determinants. Finally, we assess the socially optimal tariff rate for this disaster resilient water provisioning service and then, discuss its policy implication.

\subsection{Socioeconomic Characteristics}

Table 3 presents the socioeconomic characteristics of the respondents in three categories: inaccessibility to functional water sources; household characteristics; and respondents' personal characteristics. About $73 \%$ of households did not have access to safe drinking water sources. These households were forced to collect water from saline and bacterially contaminated water sources. About $44 \%$ and $55 \%$ of households did not have access to functional PSF and STW sources, respectively. Household size is relatively small, with an average of four members per household. However, all economically active members of households experience an average annual loss of 3.6 work days due to waterborne diseases. For the purpose of fetching drinking water, household members spend more 
Table 3 Socioeconomic characteristics of the study respondents in Dacope upazila, Khulna District, Southwestern Bangladesh Source Authors' calculation; PSF: pond sand filter; STW: shallow tube well

\begin{tabular}{|c|c|c|c|c|}
\hline Variable & Explanation & Mean & Min & Max \\
\hline \multicolumn{5}{|c|}{ Non-accessibility to functional water sources } \\
\hline No access to functional sources & 1 if do not have access to functional sources & 0.73 & 0 & 1 \\
\hline No access to functional PSF & 1 if do not have access to functional PSF & 0.44 & 0 & 1 \\
\hline No access to functional STW & 1 if do not have access to functional STW & 0.55 & 0 & 1 \\
\hline \multicolumn{5}{|l|}{ Household characteristics } \\
\hline Work days lost & $\begin{array}{l}\text { All Economically active members annual work days } \\
\text { lost due to waterborne diseases in a household }\end{array}$ & 3.59 & 0 & 180 \\
\hline Fetching time & Total time in minutes to fetch water daily & 39.31 & 0 & 100 \\
\hline Household size & Number of members in a household & 4.28 & 2 & 8 \\
\hline Total income & Monthly household income (1000 BDT/month) & 9.39 & 2.5 & 75 \\
\hline \multicolumn{5}{|c|}{ Respondents' personal characteristics } \\
\hline Age & Age of respondents & 45.65 & 24 & 90 \\
\hline Education & Years of schooling of respondents & 6.52 & 0 & 17 \\
\hline
\end{tabular}

than half an hour per day. Inaccessibility to functional water sources reduces the working hours of economically active members of the surveyed households. Households in the study area are relatively poor, with an average monthly household income of only about BDT 9500 (less than USD $120)$, compared to the national average of about BDT 16,000 (USD 189) (BBS 2016). Substantial losses of work days, time fetching water, and time invested in avertive (that is, water conservation and purification) and mitigating (that is, visiting doctors, medication, taking care of ill household members) measures impose additional burdens on these low-income households. The average age and education of respondents are around 46 years and 7 years of schooling, respectively. Household respondents are on average middle-aged, with very low level of education.

\subsection{Health Impacts of Drinking Water from Nonfunctional Water Sources}

Figure 1 compares the disease profiles of households that have access to functional water sources and households that do not. Diarrheal outbreaks are almost $15 \%$ higher in households with no access to functional water sources. About $72 \%$ of the households that fetch water from nonfunctional sources report at least one member of their household as suffering from indigestion. This rate is almost $30 \%$ higher than for households that have access to functional water sources. Figure 1 also shows the prevalence rate of suffering from gynecological disorders, such as miscarriage, (pre)eclampsia, and lowering of the uterus (due to carrying heavy water jars for longer distances when fetching water) in female members of households with no

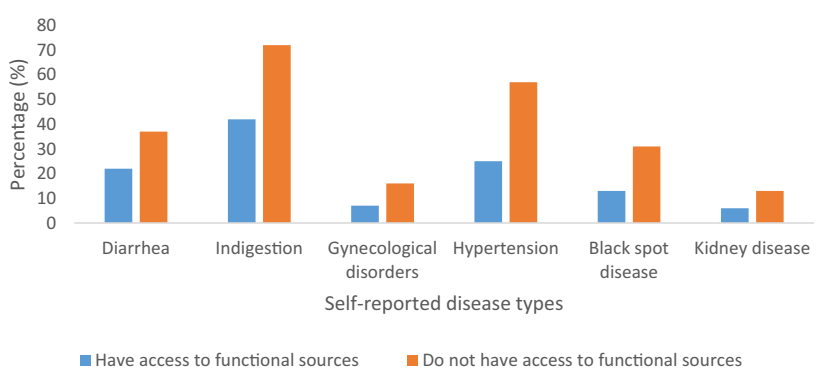

Fig. 1 Comparative self-reported disease profile between households with and without access to functional water sources in the study area in Dacope upazila, Khulna District, Southwestern Bangladesh

access to functional water sources, which was $16 \%$ higher than for females in households with access to functional water sources.

The prevalence of at least one household member suffering from hypertension is around $57 \%$ and $25 \%$ among nonfunctional and functional water source users, respectively. Drinking highly saline water from nonfunctional water sources might increase the risk of heart attack and stroke due to hypertension induced cardiovascular and renal diseases (Talukder et al. 2016). Suffering from kidney related diseases is also $7 \%$ higher among the households drinking water from nonfunctional sources compared to their counterpart group. Though the prevalence rate of different diseases was self-reported and was analyzed through simple graphic illustration, prevalence of these chronic diseases due to contaminated water from nonfunctional sources are comparable to the results in other studies (Appel 2010; Khan et al. 2011; Abedin et al. 2012). 
Ensuring access to functional water sources is pivotal to reducing waterborne health risks in the study area.

\subsection{Households' Willingness to Pay for Improved Disaster Resilient Water Sources}

The majority of the respondents $(85 \%)$ were willing to pay for developing improved disaster resilient water provisioning systems. Among the rest of the respondents, 9\% were not willing to pay; they believed providing safe water is solely a government responsibility. The remaining $6 \%$ rejected this contingent market-they believed that funds might be misused. No respondent declined WTP due to income constraints. The $15 \%$ unwilling responses are treated as protest bids. We dropped these invalid protestbid responses in the process of estimating WTP for an improvement. While, on the one hand, simply dropping these responses would yield sample selection bias and affect the estimates used for policy inferences (Strazzera, Genius, et al. 2003), on the other hand, in this case, the nonexistence of significant differences in the covariates between the positive WTP response group and the invalid response group gave us justifications to drop these invalid responses while estimating WTP (Vella 1998; Strazzera, Scarpa, et al. 2003).

\subsection{Households' Preference toward Disaster Resilient Improved Water Interventions}

Table 4 shows the preferences toward four improvement scenarios (see Table 2), which are almost evenly distributed, varying from 22 to $28 \%$. The highest number of respondents $(28 \%)$ preferred improvement scenario 4 , the most comprehensive disaster resilient PSF intervention, which is able to provide good quality drinking water with the highest possible coverage. In contrast, people preferred improvement scenario 2 the least, which indicates that refunctionalizing and installing pond sand filters in nonPSF ponds with higher payment, but without sufficient quality control, would not solve the problem. Improvement scenarios 1 and 3 were both preferred by $25 \%$ of the respondents.

Table 4 also shows households' WTP for different water improvement alternatives. The results show that around $85 \%(33.3 \%+51.9 \%)$ of the households that preferred scenario 1 accepted at least the initial bid of BDT 100 per month (column 6 and column 8). Of these $85 \%$ households, almost $52 \%$ accepted the higher follow-up bid of BDT 150, implying that households that prefer a low-cost improvement plan were willing to pay more than BDT 150 per month to refunctionalize and manage the damaged pond sand filters (column 8). A declining rate $(55 \%, 41 \%$, and $23 \%$ for improved scenarios 2-4 respectively) of accepting at least the initial bids for costlier improvement scenarios was also observed. For example, the rate of accepting at least the initial bid of BDT 400 was $23 \%(12.3 \%+10.5 \%)$ (column 6 and column 8). In contrast, rejecting at least the initial bid but accepting lower follow-up bid or no bid rose to $77 \%(40.4 \%+36.8 \%)$ for the costliest improvement scenario 4 from only $15 \%(9.3 \%+5.6 \%)$ for the cheapest improvement scenario 1 (column 2 and column 4). Therefore, accepting initial bid and follow-up higher bid decline while accepting lower follow-up bid and no bid increase with the increase in initial bid value level. Households overall preferred the most disaster resilient improved water intervention at the lowest possible cost. This finding was expected and consistent with a well-developed CV framework (Carson 2000; Banga et al. 2011).

Table 4 Households' preferences for the four water improvement scenarios in the study area in Dacope upazila, Khulna District, Southwestern Bangladesh

\begin{tabular}{|c|c|c|c|c|c|c|c|c|c|c|c|}
\hline \multirow{4}{*}{$\begin{array}{l}\text { Improvement } \\
\text { Column no. }\end{array}$} & \multirow[t]{4}{*}{ Initial bid } & \multicolumn{4}{|c|}{ Accepting lower bid or no bid } & \multicolumn{6}{|c|}{ Accepting at least initial bid } \\
\hline & & \multirow{2}{*}{\multicolumn{2}{|c|}{$\begin{array}{l}\text { Rejecting both } \\
\text { initial and lower bid } \\
\text { No-No }\end{array}$}} & \multirow{2}{*}{\multicolumn{2}{|c|}{$\begin{array}{l}\text { Rejecting initial bid } \\
\text { but accepting lower } \\
\text { bid } \\
\text { No-Yes }\end{array}$}} & \multirow{2}{*}{\multicolumn{2}{|c|}{$\begin{array}{l}\text { Accepting initial bid } \\
\text { but rejecting higher bid } \\
\text { Yes-No }\end{array}$}} & \multicolumn{4}{|c|}{$\begin{array}{l}\text { Accepting both initial and } \\
\text { higher bid }\end{array}$} \\
\hline & & & & & & & & \multicolumn{2}{|c|}{ Yes-Yes } & \multicolumn{2}{|c|}{ Total } \\
\hline & & $\begin{array}{l}\text { Freq } \\
\text { (1) }\end{array}$ & $\begin{array}{l}\% \\
(2)\end{array}$ & $\begin{array}{l}\text { Freq } \\
\text { (3) }\end{array}$ & $\begin{array}{l}\% \\
(4)\end{array}$ & $\begin{array}{l}\text { Freq } \\
\text { (5) }\end{array}$ & $\begin{array}{l}\% \\
(6)\end{array}$ & $\begin{array}{l}\text { Freq } \\
\text { (7) }\end{array}$ & $\begin{array}{l}\% \\
(8)\end{array}$ & Freq & $\%$ \\
\hline Improvement Scenario 1 & 100 & 3 & 5.6 & 5 & 9.3 & 18 & 33.3 & 28 & 51.9 & 54 & 25 \\
\hline Improvement Scenario 2 & 200 & 7 & 14.9 & 14 & 29.8 & 15 & 31.9 & 11 & 23.4 & 47 & 22 \\
\hline Improvement Scenario 3 & 300 & 13 & 24.1 & 19 & 35.2 & 12 & 22.2 & 10 & 18.5 & 54 & 25 \\
\hline \multirow[t]{2}{*}{ Improvement Scenario 4} & 400 & 21 & 36.8 & 23 & 40.4 & 7 & 12.3 & 6 & 10.5 & 57 & 28 \\
\hline & Total & 44 & 20.75 & 61 & 28.77 & 52 & 24.53 & 55 & 25.94 & 212 & 100 \\
\hline
\end{tabular}




\subsection{Determinants of Willingness to Pay}

The WTP estimates are unbiased when the DBDC model does not suffer from starting point bias (Alberini 1995). To avoid this bias, we did not ask any initial bid randomly and instead, presented all four scenarios with the initial bid to the respondents. They were then asked to state their preference for any of the disaster resilient improved water interventions. After revealing their preferences, we asked about the follow-up higher and lower bids. Therefore, this bidding design did not suffer from starting point bias because the respondents showed their preference for the initial bid and desired improvement based on their value judgment. We then checked the models' predicting capability of explaining the variation in WTP. A hypothesis regarding all the coefficients, except constant term equals zero, was tested simultaneously for each model. The test results suggest that both models are sufficiently capable of explaining that variation and the first model is found more efficient (wald $\chi^{2}(7)$ for first model $=14.14(p<0.000)$; wald $\chi^{2}(7)$ for second model $=15.35(p<0$ in Table 5$)$.

Table 5 shows that no access to functional water sources significantly determines households' WTP for disaster resilient improved water interventions in both the models. In the first model, households without access to any functional sources have an almost BDT 36 higher WTP than their counterparts. The second model disaggregates no access to functional sources into source specific inaccessibility-no access to functional PSF and no access to functional STW. In this regard, "access to functional PSF" and "access to functional STW" are the reference dummies. Households without access to PSF water exhibit an around BDT 39 higher WTP (significant at 5\%), while households without access to STW water were more likely to be indifferent to paying compared to their counterparts. The plausible explanation is that they are less willing to collect water even from a functional STW because the water often contains excessive sandy and arsenic materials in this study area (Harun and Kabir 2013). The higher WTP by households with no access to functional water sources is understandable from Fig. 1-households deprived of accessing water from functional sources experienced a higher prevalence of severe waterborne diseases. They incurred more avertive and medication costs, and higher work day losses along with sufferings from diseases. Higher costs for curing waterborne diseases motivated them to pay more, compared to their counterparts, for disaster resilient improved water interventions. Time required for fetching water and education are more likely to affect WTP in the first model, while age of the respondents is less likely to affect WTP in both models. Though household income, family size, and waterborne disease induced work day loss are not found to explain households'
Table 5 Determinants of households' willingness to pay (WTP) for improved water sources in the study area in Dacope upazila, Khulna District, Southwestern Bangladesh

\begin{tabular}{|c|c|c|}
\hline $\begin{array}{l}\text { Model } \\
\text { Covariates }\end{array}$ & $\begin{array}{l}\text { (1) } \\
\text { Coefficient }\end{array}$ & $\begin{array}{l}(2) \\
\text { Coefficient }\end{array}$ \\
\hline $\begin{array}{l}\text { Households do not have access to } \\
\text { functional water sources }\end{array}$ & $\begin{array}{l}36.37 * \\
(21.75)\end{array}$ & \\
\hline $\begin{array}{l}\text { Households do not have access to } \\
\text { functional STW }\end{array}$ & & $\begin{array}{l}5.81 \\
(19.54)\end{array}$ \\
\hline $\begin{array}{l}\text { Households do not have access to } \\
\text { functional PSF }\end{array}$ & & $\begin{array}{l}39.15 * * \\
(19.69)\end{array}$ \\
\hline Work day lost & $\begin{array}{l}0.66 \\
(0.64)\end{array}$ & $\begin{array}{l}0.61 \\
(0.65)\end{array}$ \\
\hline Time spent fetching water & $\begin{array}{l}0.69 * \\
(0.40)\end{array}$ & $\begin{array}{l}0.64 \\
(0.41)\end{array}$ \\
\hline Age of respondents & $\begin{array}{l}-1.84 * * \\
(0.83)\end{array}$ & $\begin{array}{l}-1.75^{* *} \\
(0.83)\end{array}$ \\
\hline Education of respondents & $\begin{array}{l}3.66^{*} \\
(2.08)\end{array}$ & $\begin{array}{l}3.36 \\
(2.11)\end{array}$ \\
\hline Household income & $\begin{array}{l}0.41 \\
(1.63)\end{array}$ & $\begin{array}{l}0.25 \\
(1.65)\end{array}$ \\
\hline Family size & $\begin{array}{l}2.58 \\
(8.48)\end{array}$ & $\begin{array}{l}3.98 \\
(8.57)\end{array}$ \\
\hline Constant & $\begin{array}{l}252.47 * * * \\
(44.65)\end{array}$ & $\begin{array}{l}254.24 * * * \\
(43.86)\end{array}$ \\
\hline Sigma & $\begin{array}{l}118.15^{* * * *} \\
(7.80)\end{array}$ & $\begin{array}{l}118.34 * * * \\
(7.84)\end{array}$ \\
\hline Wald statistics $\left(\chi^{2}\right)$ & $\begin{array}{l}\chi^{2}(7)=14.15 \\
p \text { value }=0.04\end{array}$ & $\begin{array}{l}\chi^{2}(7)=15.35 \\
p \text { value }=0.05\end{array}$ \\
\hline Observations & 212 & 212 \\
\hline
\end{tabular}

Standard errors are included in parentheses

$P S F$ pond sand filter; $S T W$ shallow tube well

$* * * p<0.01, * * p<0.05, * p<0.1$

WTP in either of the models, these variables exhibit expected signs. The positive coefficient for water fetching time implies that a 10-minute increase in fetching time increases households' WTP by BDT 7 . The negative association between age and WTP implies that young respondents are willing to pay more for improvement than those with older respondents. A one-year younger respondent is on average willing to pay BDT 2 more than a senior respondent. Altaf and Deshazo (1996) pointed out that older people are more reluctant to adopt new technologies, lowering their WTP for improvement. The expected positive coefficient for the education variable implies that households' WTP rises with an increase in the years of schooling of the respondents. Banga et al. (2011) regarded respondents' educational attainment as a good predictor of adopting good environmental practices to protect themselves and their dependents from potential health risks. As 


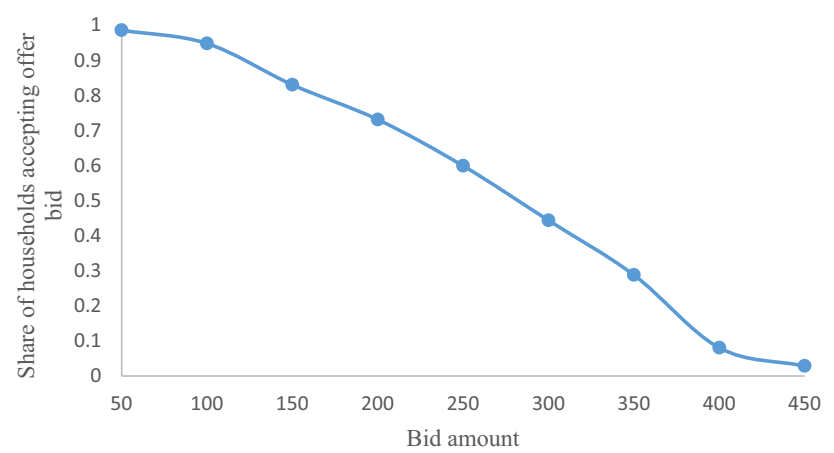

Fig. 2 Households' willingness to pay (WTP) for disaster resilient improved water interventions in the study area in Dacope upazila, Khulna District, Southwestern Bangladesh

a consequence, educated people are willing to pay more for disaster resilient improved water interventions. Model 1 shows that an additional year of schooling increases WTP by more than BDT 3.5. However, household income is not a significant determinant of WTP though it exhibits the expected sign. The reason is that the scarcity of safe drinking water in the study area is so widespread that both low- and higher-income groups exhibit a similar attitude toward disaster resilient improved water interventions. Few households with an income much higher than average have additional sources of safe drinking water, such as rainwater harvesters, in their home, but are not willing to pay higher than lower-income households.

\section{Computing Willingness to Pay and Policy Measures}

The computation of WTP helps policymakers to determine the optimal tariff for an improvement. The computed mean WTP is BDT 263 with an interval of $245-282$ at $95 \%$ confidence level. Households are on average willing to pay BDT 263 per month. Figure 2 shows that almost all of the valid respondents were willing to pay for an improvement at BDT 50. More than 90\% show a WTP at BDT 100 . Households' preference for a disaster resilient improved water intervention fell with the increase in tariff rate. ${ }^{2}$ Only less than $1 \%$ of the sampled households were willing to accept the offer at BDT 450. The median WTP is around BDT 265 per month (almost the same as the mean WTP), indicating that $50 \%$ of the households were willing to pay BDT 265 per month for disaster resilient improved water provisioning services. In this regard, formulating policies by applying mean WTP would not suffer from outlier effects.

\footnotetext{
2 Tariff rate is approximated from amount of offer bids
}

The project costs associated with the construction of disaster resilient improved pond sand filters depend on installations and annual maintenances. Installing a PSF requires, on average, BDT 41,700-62,600 (USD 493-740) with an average maintenance cost of BDT 4200 (USD 50) per year (Harun and Kabir 2013). Personal communication with a DPHE engineer indicated that a disaster resilient improved PSF, as described in scenario 4, would require around BDT 84,000 (USD 1000) with BDT 8400 (USD $100)$ maintenance cost per year. One PSF could support around 60 households. There are 22,295 households and thus, about 372 PSFs are required to support these households in the selected five unions of Dacope upazila (BBS 2015). Therefore, around USD 0.41 million is required (including installation and servicing cost) for the first year of the project. The one-time installation cost for these PSFs is USD 0.372 million and USD 37.2 thousand has to be spent for servicing these PSFs per year. For computing total cost of this project over its life span, we followed Das et al.'s (2019) approach where project's life span and discount rate were 10-year and $10 \%$ respectively. We computed the present value of one-time installment and 10-year servicing costs for this project of USD 0.52 million. Accordingly, we used WTP estimates at different bids with a view to computing revenue earnings from this project. We computed present values of 10 -year revenue streams at different tariff rates and then, determining through simulation of present valued cost and revenue the socially optimal tariff for installing and maintaining the most disaster resilient improved water intervention. The simulation result is presented in Fig. 3.

Imposing the mean WTP of BDT 263 per month as the monthly water tariff, only about 11.1 thousand households (or around $50 \%$ of the households) would afford to accept this tariff rate, the present value of 10-year revenue streams would be about BDT 624 (USD 7.37) million, which is

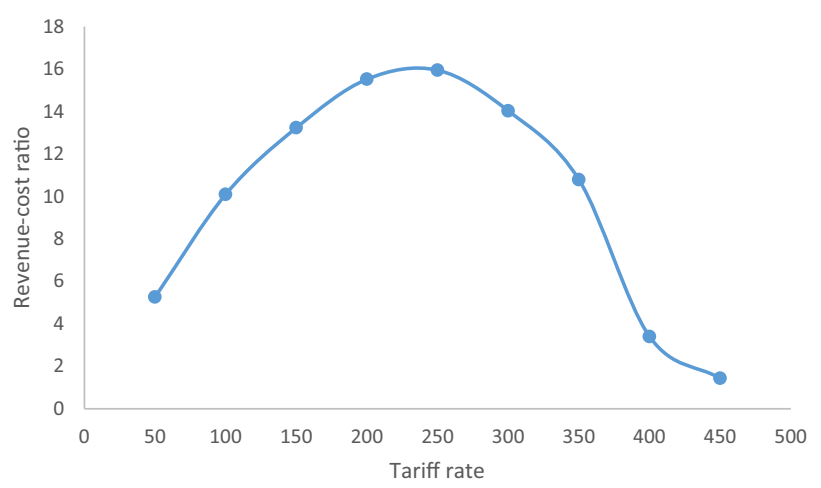

Fig. 3 Determining the socially optimal tariff for the most disaster resilient improved water intervention in the study area in Dacope upazila, Khulna District, Southwestern Bangladesh 
14.30 times of the project's present value of the total cost (Fig. 3). If tariff rate reduced to BDT 250, the present value of project's revenue reaches its maximum BDT 694 (USD 8.20) million, which is almost 15.90 times of present value of total costs. In result, additional 2.2 and total 13.4 thousand households would now afford to accept this reduced tariff rate. This is the economically optimal tariff rate because at this rate the water supply authority would likely maximize their financial benefits despite the fact that only around $60 \%$ of the households may be able to afford this service at this price. The other $40 \%$ of the households would be excluded from access to this improvement. Therefore, BDT 250 is also not a socially optimal tariff. Beyond this point, increasing or decreasing the tariff would reduce the water supply authority's financial benefit (Fig. 3). Increasing the tariff rate would decrease the percentage of households able to afford the facilities of the project (Fig. 2). But if the tariff rate is reduced to BDT 100 per month, 21 thousand households would now afford to accept this tariff rate, the present value of the generated revenue would be BDT 439.52 (USD 5.19) million, which is about 10 times of present value of the total cost, and in consequence, about $95 \%$ of the households would be able to afford this service. It is even possible to create accessibility for almost $99 \%$ of the households through lowering the tariff to BDT 50 per month. This tariff would still generate revenue equivalent to 5.25 times of the total cost. Since the BDT 50 tariff rate would guaranty the maximum number of households to access an improved disaster resilient water provisioning system, it would be the socially acceptable optimum tariff rate. This project would be sustainable for a long period since the revenue generated at any of the tariff rates exceeds the associated cost of the service.

For generalizing our policy implications, we compare our findings with some recently published articles on similar issues. Islam et al. (2018) and Dey et al. (2018) computed monthly mean WTP at BDT 193 and BDT 129 for improved drinking water in Mongla upazila of Bagerhat District and Tala upazila of Satkhira District, respectively. These estimates are much less than our computed WTP in absolute monetary terms. This variation in WTP can possibly be explained by the variations in the improvement plan along with differences in household features, regional characteristics, and the year of data collection. Our study offered additional disaster resilient features along with water quality improvement, which might encourage respondents to pay more. Thus, our computed mean WTP exceeds the WTP reported in some other comparable studies. However, WTP as a share of income varies from 2 to $3 \%$ in southwestern coastal Bangladesh (Islam et al. 2018; Dey et al. 2018). Our computed mean WTP accounts for about $2.8 \%$ of households' monthly income. To some extent, the findings and policy implications (imposing BDT 50 per month as the socially optimum tariff rate) from this study could be applicable to other comparable disasterprone upazilas of southwestern coastal Bangladesh.

\section{Conclusion}

Catastrophic cyclone-2009 Cyclone Aila-damaged the functionality of around $23 \%$ of total water interventions completely and reduced the water quality of undamaged interventions dramatically in Dacope upazila, Khulna District of Bangladesh. In consequence, through drinking saline water, people of this region take in sodium chloride many times the WHO recommended limit, causing outbreaks of waterborne chronic diseases. This study revealed that about $73 \%$ of households in the study area do not have access to any functional water sources, of which about $44 \%$ do not have access to pond sand filters. Households without access to functional water sources are affected by various diseases. To fight this terrible situation, there is no other alternative than to develop disaster resistant improved water supply systems, since this region is highly prone to cyclones. In the past, these interventions were constructed and managed by various NGOs and government agencies. However, lack of fund and monitoring by these organizations impedes the refunctionalization of these interventions. Moreover, without the involvement and contribution of community people, it is very difficult to develop sustainable disaster resilient improved water interventions. With a view to assessing community peoples' ability to raise funds for refunctionalizing these water interventions, this study estimated households' WTP for disaster resilient safe drinking water sources since disasters frequently damage water interventions in this region.

We chose Dacope upazila of Khulna District as the study site, one of the locations on the southwest coast that was highly affected by cyclones Sidr and Aila. The study showed that around $85 \%$ of households are willing to pay for the disaster resilient improved water provisioning system. The rest reject the designed hypothetical contingent market because they suspect that the raised funds might be misused or the government will not accomplish the task for them. We safeguarded our CV design from all three potential biases-strategic, selection, and starting point biases-by following approaches emphasized in the literature. Households' mean WTP is BDT 263 per month. The variation in WTP is significantly explained by non-accessibility to functional water sources, water fetching time, and age and education of the respondents. Mean WTP of households without access to any safe drinking water interventions is BDT 36 more and households without access to pond sand filters is BDT 39 more than the WTP 
of their counterparts. Household WTP varies between BDT 50-450 per month. About $99 \%$ of households prefer disaster resilient improved water intervention at a charge of BDT 50 per month, while less than $1 \%$ show a positive response to a bid of BDT 450 per month.

A tariff at mean WTP generates revenues almost 14.30 times higher than the establishment and management cost of the project. But, reduction from mean WTP to BDT 250 maximizes revenues for the water governing authority, which is about 15.90 times higher than the total project costs. However, imposition of a tariff at BDT 250 per month would exclude around $40 \%$ of households from access to this disaster resilient safe drinking water provisioning project. This exclusion would create social unrest over water or a free riding problem over the disaster resilient improved water provisioning system. This situation is socially undesirable and conflicts with the purpose of initiating this project. Our simulation results reveal that it is possible to create year-round access for almost $100 \%$ households by reducing the tariff rate from BDT 250 to BDT 50 per month without causing a financial deficit for project investment. Even at this lowest rate, it is still possible to generate revenue equivalent to almost 5.25 times the associated costs. Therefore, BDT 50 is a socially acceptable optimum tariff rate that eliminates free riders and creates year-round access to disaster resilient safe drinking water sources along with making a surplus. Thus, financial contributions from local community people can ensure the development of sustainable disaster resilient safe drinking water sources in disaster-prone southwestern coastal Bangladesh.

Acknowledgements The authors would like to thank the anonymous reviewers and editors for their valuable comments and suggestions to improve this article.

Open Access This article is distributed under the terms of the Creative Commons Attribution 4.0 International License (http://creativecommons. org/licenses/by/4.0/), which permits unrestricted use, distribution, and reproduction in any medium, provided you give appropriate credit to the original author(s) and the source, provide a link to the Creative Commons license, and indicate if changes were made.

\section{References}

Abedin, M.A., and R. Shaw. 2018. Constraints and coping measures of coastal community toward safe drinking water scarcity in Southwestern Bangladesh. In Science and technology in disaster risk reduction in Asia, ed. R. Shaw, K. Shiwaku, and T. Izumi, 431-452. Academic Press. Cambridge.

Abedin, M.A., and R. Shaw. 2014. Community-level arsenic mitigation practices in southwestern part of Bangladesh. In Water insecurity: A social dilemma, ed. M.A. Abedin, U. Habiba, and R. Shaw, 51-73. Bingley, UK: Emerald Group Publishing.

Abedin, M.A., U. Habiba, and R. Shaw. 2012. Impacts of salinity, arsenic and drought in South-western Bangladesh. In
Environment disaster linkages, ed. R. Shaw, and T. Phong, 165-193. Bingley, UK: Emerald Group Publishing.

Abedin, M.A., U. Habiba, and R. Shaw. 2014. Community perception and adaptation to safe drinking water scarcity: Salinity, arsenic, and drought risks in coastal Bangladesh. International Journal of Disaster Risk Science 5(2): 110-124.

Alberini, A. 1995. Optimal designs for discrete choice contingent valuation surveys: Single-bound, double-bound, and bivariate models. Journal of Environmental Economics and Management 28(3): 287-306.

Altaf, M.A., and J.R. Deshazo. 1996. Household demand for improved solid waste management: A case study of Gujranwala, Pakistan. World Development 24(5): 857-868.

Appel, L.J. 2010. ASH position paper: Dietary approaches to lower blood pressure. Journal of the American Society of Hypertension 4(2): 79-89.

Arrow, K., R. Solow, P.R. Portney, E.E. Leamer, R. Radner, and H. Schuman. 1993. Report of the NOAA panel on contingent valuation. Federal Register 58(10): 4601-4614.

Banga, M., R.B. Lokina, and A.F. Mkenda. 2011. Households' willingness to pay for improved solid waste collection services in Kampala city, Uganda. The Journal of Environment \& Development 20(4): 428-448.

Baten, M.A., and R.A.M. Titumir. 2016. Environmental challenges of trans-boundary water resources management: The case of Bangladesh. Sustainable Water Resources Management 2(1): 13-27.

BBS (Bangladesh Bureau of Statistics). 2015. Population \& housing census-2011: Community report Khulna. Dhaka, Bangladesh: BBS. http://203.112.218.65:8008/WebTestApplication/userfiles/ Image/PopCen2011/Com_Khulna.pdf. Accessed 24 Aug 2019.

BBS (Bangladesh Bureau of Statistics). 2016. Bangladesh HIES: Household income per month. Dhaka, Bangladesh: BBS. https:// www.ceicdata.com/en/bangladesh/household-income-and-expen diture-survey-household-income-per-month/hies-householdincome-per-month. Accessed 2 Feb 2018.

Cameron, T.A., and M.D. James. 1987. Efficient estimation methods for "closed-ended" contingent valuation surveys. The Review of Economics and Statistics 69(2): 269-276.

Carson, R.T. 2000. Contingent valuation: A user's guide. Environmental Science and Technology 34(8): 1413-1418.

Curry, E. 2010. Water scarcity and the recognition of the human right to safe freshwater. Northwestern Journal of International Human Rights 9(1): 103-121.

Das, D.K., M.S. Islam, S. Hadiujjaman, C.B. Dutta, and M.M. Morshed. 2019. Health cost of salinity contamination in drinking water: Evidence from Bangladesh. Environmental Economics and Policy Studies 21(3): 371-397.

Dasgupta, S., B. Laplante, S. Murray, and D. Wheeler. 2011. Exposure of developing countries to sea-level rise and storm surges. Climatic Change 106(4): 567-579.

Dekker, T., R. Brouwer, M. Hofkes, and K. Moeltner. 2011. The effect of risk context on the value of a statistical life: a Bayesian meta-model. Environmental and Resource Economics 49(4): 597-624.

Dey, N.C., M. Parvez, R. Saha, M.R. Islam, T. Akter, M. Rahman, M. Barua, and A. Islam. 2018. Water quality and willingness to pay for safe drinking water in Tala Upazila in a coastal district of Bangladesh. Exposure and Health. https://doi.org/10.1007/ s12403-018-0272-3.

DPHE (Department of Public Health Engineering). 2009. Annual report. Khulna, Bangladesh: DPHE.

DPHE (Department of Public Health Engineering). 2015. Annual report. Khulna, Bangladesh: DPHE.

EHS (Environment and Human Security). 2011. World risk report 2011. Tokyo, Japan: United Nations University. 
EPA (Environmental Protection Agency). 2000. Handbook for noncancer health effects valuation. Washington, DC: EPA.

Ettehad, D., C.A. Emdin, A. Kiran, S.G. Anderson, T. Callender, J. Emberson, J. Chalmers, A. Rodgers, and K. Rahimi. 2016. Blood pressure lowering for prevention of cardiovascular disease and death: A systematic review and meta-analysis. Lancet 387(10022): 957-967.

Finan, T. 2009. Storm warnings: The role of anthropology in adapting to sea level rise in Southwestern Bangladesh. In Anthropology and climate change: From encounters to actions, ed. S.A. Crate, and M. Nuttall, 175-185. Walnut Creek, CA: Left Coast Press.

Habiba, U., M.A. Abedin, R. Shaw, and A.W.R. Hassan. 2014. Salinity-induced livelihood stress in coastal region of Bangladesh. In Water insecurity: A social dilemma, ed. M.A. Abedin, U. Habiba, and R. Shaw, 139-165. Bingley, UK: Emerald Group Publishing.

Habiba, U., R. Shaw, and Y. Takeuchi. 2012. Farmer's perception and adaptation practices to cope with drought: Perspectives from Northwestern Bangladesh. International Journal of Disaster Risk Reduction 1(1): 72-84.

Hanemann, M., and B. Kanninen. 2001. The statistical analysis of discrete-response CV data. In Valuing environmental preferences: Theory and practice of the contingent valuation method in the US, EU, and developing countries, ed. I.J. Bateman, and K.G. Willis, 302-441. Oxford: Oxford University Press.

Harun, M.A.Y.A., and G.M.M. Kabir. 2013. Evaluating pond sand filter as sustainable drinking water supplier in the Southwest coastal region of Bangladesh. Applied Water Science 3(1): 161-166.

Islam, M., M.A. Akber, and M.A. Islam. 2018. Willingness to pay for improved drinking water in southwest coastal Bangladesh. Water Supply 19(1): 1-10.

JAC (Joint Assessment Consortium). 2009. In-depth recovery needs assessment of Cyclone Aila affected areas. ActionAid, concern Worldwide, DanChurchAid, MuslimAid, Islamic Relief, OxfamGB and Save the Children-UK. https://reliefweb.int/sites/reliefweb. int/files/resources/F6603B7EF22A16B4C125768D004B1190Full_Report.pdf. Accessed 2 Jan 2018.

Johansson, P.O. 1995. Evaluating health risks: An economic approach. Cambridge: Cambridge University Press.

Kealy, M.J., M. Montgomery, and J.F. Dovidio. 1990. Reliability and predictive validity of contingent values: Does the nature of the good matter? Journal of Environmental Economics and Management 19(3): 244-263.

Khan, A.E., W.W.Xun, H. Ahsan, and P. Vineis. 2011. Climate change, sea-level rise, and health impacts in Bangladesh. Environment: Science and Policy for Sustainable Development 53(5): 18-33.

Khan, N.I., R. Brouwer, and H. Yang. 2014. Household's willingness to pay for arsenic safe drinking water in Bangladesh. Journal of Environmental Management 143(1): 151-161.

Khanam, M.A., W. Lindeboom, A. Razzaque, L. Niessen, and A.H. Milton. 2015. Prevalence and determinants of pre-hypertension and hypertension among the adults in rural Bangladesh: findings from a community-based study. BMC Public Health 15(1): 203-212.

Louviere, J.J., D.A. Hensher, and J.D. Swait. 2000. Stated choice methods: Analysis and applications. Cambridge: Cambridge University Press.

Lusk, J.L. 2003. Effects of cheap talk on consumer willingness-to-pay for golden rice. American Journal of Agricultural Economics 85(4): 840-856.

Mahmuduzzaman, M., Z.U. Ahmed, A.K.M. Nuruzzaman, and F.R.S. Ahmed. 2014. Causes of salinity intrusion in coastal belt of
Bangladesh. International Journal of Plant Research 4(4A): 8-13.

Mallick, B., and J. Vogt 2011. Social supremacy and its role in local level disaster mitigation planning in Bangladesh. Disaster Prevention and Management: An International Journal 20(5): 543-556.

McConnell, K.E. 1995. Issues in estimating benefits with non-market methods. Working Paper No. 308. Washington, DC: InterAmerican Development Bank.

McFadden, D.L. 1973. Conditional logit analysis of qualitative choice behavior. In Frontiers of econometrics, ed. P. Zarembka, 105-142. New York: Wiley.

Parry, M.L., O.F. Canziani, J.P. Palutikof, P.J. van der Linden, and C.E. Hanson (eds.). 2007. AR4 Climate change 2007: Impacts, adaptation, and vulnerability. Contribution of Working Group II to the fourth assessment report of the Intergovernmental Panel on Climate Change. Cambridge: Cambridge University Press.

Rahman, A.A., and P. Ravenscroft (eds). 2003. Groundwater resources and development in Bangladesh-Background to the arsenic crisis, agricultural potential and the environment. Dhaka, Bangladesh: The University Press Limited.

Rahman, M., and A.K. Bhattacharya. 2006. Salinity intrusion and its management aspects in Bangladesh. Journal of Environmental Hydrology 14(1): 1-8.

Rasheed, S., A.K. Siddique, T. Sharmin, A.M.R. Hasan, S.M.A. Hanifi, M. Iqbal, and A. Bhuiya. 2016. Salt intake and health risk in climate change vulnerable coastal Bangladesh: What role do beliefs and practices play? PloS One 11(4): Article e0152783.

Safiuddin, M.D., M.M. Karim, T. Murphy, and J. Guo. 2003. Water resources management in the remediation of groundwater arsenic contamination in Bangladesh. In Aquatic arsenic toxicity and treatment, ed. T. Murphy, and J. Guo, 1-17. Leiden, Netherlands: Backhuys Publishers.

Scheelbeek, P.F., A.E. Khan, S. Mojumder, P. Elliott, and P. Vineis. 2016. Drinking water sodium and elevated blood pressure of healthy pregnant women in salinity-affected coastal areas. Hypertension 68(2): 464-470.

Strazzera, E., M. Genius, R. Scarpa, and G. Hutchinson. 2003. The effect of protest votes on the estimates of WTP for use values of recreational sites. Environmental and Resource Economics 25(4): 461-476.

Strazzera, E., R. Scarpa, P. Calia, G.D. Garrod, and K.G. Willis. 2003. Modelling zero values and protest responses in contingent valuation surveys. Applied Economics 35(2): 133-138.

Talukder, M.R.R., S. Rutherford, D. Phung, M.Z. Islam, and C. Chu. 2016. The effect of drinking water salinity on blood pressure in young adults of coastal Bangladesh. Environmental Pollution 214(1): 248-254.

Vella, F. 1998. Estimating models with sample selection bias: A survey. Journal of Human Resources 33(1): 127-169.

WHO (World Health Organization). 2004. Occurrence of cyanobacterial toxins (microcystins) in surface waters of rural Bangladesh-Pilot study. Geneva: WHO.

WHO (World Health Organization). 2012. Guideline: Sodium intake for adults and children. Geneva: WHO.

WHO (World Health Organization). 2018. Country profile Bangladesh. In Noncommunicable diseases country profiles. Geneva: WHO. https://www.who.int/nmh/countries/bgd_en.pdf?ua=1. Accessed 22 Aug 2019.

World Economic Forum. 2019. The global risks report 2019, 14th edn. http://wef.ch/risks2019. Accessed 21 Aug 2019.

Yokota, H., K. Tanabe, M. Sezaki, Y. Akiyoshi, T. Miyata, K. Kawahara, S. Tsushima, H. Hironaka, et al. 2001. Arsenic contamination of ground and pond water and water purification system using pond water in Bangladesh. Engineering Geology 60(1-4): 323-331. 